\title{
Pemodelan Protein dengan Homology Modeling menggunakan SWISS-MODEL Protein Modeling with Homology Modeling using SWISS-MODEL
}

\author{
Noer Komari ${ }^{1}$, Samsul Hadi ${ }^{2}$, Eko Suhartono ${ }^{3}$ \\ ${ }^{1}$ Program Studi Kimia, Fakultas Matematika dan Ilmu Pengetahuan Alam, Universitas Lambung Mangkurat \\ ${ }^{2}$ Program Studi Farmasi, Fakultas Matematika dan Ilmu Pengetahuan Alam, Universitas Lambung Mangkurat \\ ${ }^{3}$ Bagian Biokimia Fakultas Kedokteran, Universitas Lambung Mangkurat
}

Alamat e-mail: nkomari@ulm.ac.id

\begin{abstract}
Abstrak - Struktur tiga dimensi (3D) protein diperlukan untuk memahami sifat dan fungsi protein. Penentuan struktur protein dengan peralatan laboratorium cukup rumit dan mahal. Alternatif metode untuk memprediksi struktur $3 D$ protein adalah metode in silico. Salah satu metode in silico adalah homology modelling. Pemodelan dilakukan dengan server SWISS-MODEL. Protein yang dimodelkan struktur 3D-nya adalah protein yang belum memiliki struktur pada database RCSB PDB. Sekuen protein didapat dari database UniProt dengan kode AOAOB6VWS2. Hasil penelitian menunjukkan terdapat 2 model yang dipilih, yaitu model-1 dengan kode template PDB 1q0e dan model-2 dengan kode template PDB 3gtv. Hasil pensejajaran sekuen dan visualisasi model menunjukkan bahwa model-1 dan model-2 identik. Evaluasi dan penilaian model-1 pada Ramachandran Plot memiliki daerah favoured sebesar 97,36\%, skor MolProbity sebesar 0.79 dan harga QMEAN 1.13. Model-1 adalah model struktur 3D protein yang baik.
\end{abstract}

Kata Kunci : homology modeling, SWISS-MODEL, struktur 3D protein

Abstract - The three-dimensional (3D) structure of proteins is necessary to understand the properties and functions of proteins. Determining protein structure by laboratory equipment is quite complicated and expensive. An alternative method to predict the $3 D$ structure of proteins is the in silico method. One of the in silico methods is homology modeling. Homology modeling is done using the SWISS-MODEL server. Proteins that will be modeled in the $3 D$ structure are proteins that do not yet have a structure in the RCSB PDB database. Protein sequences were obtained from the UniProt database with code AOAOB6VWS2. The results showed that there were two models selected, namely model-1 with the PDB code template 1q0e and model-2 with the PDB code template $3 g t v$. The results of sequence alignment and model visualization show that model1 and model-2 are identical. The evaluation and assessment of model-1 on the Ramachandran Plot have a Favored area of $97.36 \%$, a MolProbity score of 0.79, and a QMEAN value is 1.13. Model-1 is a good 3D protein structure model.

Keywords: $3 D$ protein structure, homology modeling, SWISS-MODEL

(C) 2020 Jurnal Jejaring Matematika dan Sains. This work is licensed under a $\underline{C C B Y-N C 4.0}$

\section{PENDAHULUAN}

Sifat dan fungsi protein secara biokimia molekular sangat ditentukan oleh struktur tiga dimensi (3D) protein. Penentuan struktur 3D protein dapat dilakukan dengan menggunakan peralatan laboratoriun, antara lain Difraksi Sinar-X, Nuclear Magmetic Resonance dan Mikroskop Elektron. Cara tersebut rumit, lama dan memerlukan biaya sangat besar untuk penentuan satu struktur protein. Cara penentuan struktur 3D protein yang lebih mudah dan murah adalah secara in silico [1].

Secara in silico ada 3 (tiga) metode pemodelan struktur 3D protein, yaitu homology modelling, fold recognition dan $a b$ initio [2,3]. Metode homology modelling menjadi pilihan terbaik untuk membangun struktur 3D protein. Homology modelling secara komputasi lebih mudah dan lebih cepat dibandingkan fold recognition dan ab initio $[2,3]$. Salah satu kelemahan metode homology meodelling adalah harus tersedia protein template [4]. Homology modelling banyak digunakan dalam virtual screening obat, disain percobaan mutagenesis dan mempelajari efek variasi sekuen. [5]
Homology modelling adalah pemodelan struktur 3D protein berdasarkan pada pensejajaran sekuen asam amino protein target dengan protein lain yang telah diketahui struktur 3D-nya secara instrumentasi. Protein yang sudah diketahui struktur 3D nya disebut sebagai template [6]. Sekuen protein yang urutan asam aminonya mirip, maka mirip juga strukturnya [7].

Berdasarkan website yang memberikan informasi struktur 3D protein, cukup banyak struktur 3D protein yang telah ditemukan. RCSB PDB (https://www.rcsb.org/search) pada Agustus 2020 melaporkan jumlah protein yang telah ditemukan sebanyak 167.518 protein. Jumlah ini relatif sangat sedikit jika dibandingkan dengan data sekuen protein yang ditemukan. Database UniProt (https://www.uniprot.org/) menunjukkan jumlah sekuen protein sebanyak 563.082. Hal ini menunjukkan bahwa penelitian penentuan struktur protein lebih lambat dibanding penelitian tentang sekuen protein. Hal ini mendorong untuk melakukan penentuan struktur protein dengan metode lain, yaitu metode homology modelling [7]. 
Ikan gabus (Channa striata) salah satu jenis ikan yang mengandung protein tinggi. Kandungan protein pada ikan gabus mencapai $90 \%$ [8]. Kajian protein ikan gabus umumnya berkaitan dengan komposisi asam amino protein. Kajian yang mengarah kepada penentuan struktur $3 \mathrm{D}$ protein ikan gabus belum banyak dilakukan.

Tujuan penelitian ini adalah membuat model struktur 3D protein ikan gabus menggunakan server SWISSMODEL. Informasi tentang struktur 3D protein ikan gabus dapat memudahkan pengembangan kajian yang berbasis struktur protein tersebut. Kajian tersebut antara lain mempelajari sifat dan struktur protein, mengkaji mekanisme interaksi dengan protein tersebut dengan senyawa lain melalui docking molekul dan mengkaji virtual screening obat terkait protein tersebut.

\section{METODE PENELITIAN}

Pemodelan protein mengikuti langkah-langkah pada server SWISS-MODEL [9]. Tahapan pemodelan adalah: penentuan sekuen target protein, identifikasi protein template, pembuatan model dan evaluasi model.

Pemilihan sekuen target protein ikan gabus (C. striata) dari website http://www.uniprot.org. Pilihan data sekuen target protein didasarkan pada data sekuen protein yang belum memiliki struktur 3D. Database UniProt menunjukkan adanya struktur protein $3 \mathrm{D}$, bila terdapat link ke RCSB Protein Data Bank (https://www.rcsb.org/search) dengan kode tertentu. Bila tidak dijumpai link RCSB PDB, maka sekuen protein tersebut belum memiliki struktur 3D. Sekuen yang dipilih adalah sekuen yang belum memiliki struktur 3D di RCSB PDB. Sekuen ini dipilih sebagai sekuen target protein.

Identifikasi protein template dilakukan pada server https://swissmodel.expasy.org/interactive. Data sekuen target protein dari UniProt dalam format FASTA di submitkan pada server SWISS-MODEL tersebut. Proses identifikasi template akan menghasilkan 50 template protein dengan parameternya. Template protein dipilih sesuai dengan parameter identity, QMEAN, dan $Q S Q E$.

Pembuatan model protein dilakukan dengan cara memilih template protein yang dihasilkan. Pembuatan model dilakukan pada server https://swissmodel.expasy.org/interactive/RGPEKv/templ ates/. Pilihan satu template protein biasanya menghasilkan 1 atau lebih model. Model yang dihasilkan dipilih sesuai parameter GMQE, QMEAN, Oligo State, Ligands, dan Similarity.

Evaluasi model dilakukan terhadap model yang dipilih pada langkah sebelumnya. Evaluasi model dilakukan pada website

https://swissmodel.expasy.org/interactive/RGPEKv/mode $\underline{\text { ls/ Evaluasi dilakukan dengan fitur "Structure }}$ Assessment". Evaluasi dilakukan pada parameter antara lain: Ramachandran Plot, Mol Probity Results, Quality Estimate, dan Residu Quality.

Pensejajaran sekuen protein model menggunakan Pairwise Sequence Alignment pada server https://www.ebi.ac.uk/Tools/psa/. Visualisasi protein model dilakukan dengan program Chimera 1.14 yang diunduh dari website https://www.cgl.ucsf.edu/chimera/.

\section{HASIL DAN PEMBAHASAN}

\section{A. Pemilihan Sekuen Target}

Protein yang dipilih adalah protein ikan gabus $(C$. striata) yang sekuen proteinnya telah ditentukan, tetapi struktur 3D nya belum ditentukan. Hasil pencarian target protein pada database UniProt dengan memasukkan kata kunci "channa striata" dan pilihan organism "CHASR", didapat sebanyak 356 protein. Data diakses pada tanggal 20 Agustus 2020.

Database UniProt menyajikan banyak sekali jenis protein ikan gabus. Sekuen target protein dipilih dari salah satu nama protein yang belum memiliki struktur 3D. Pada penelitian ini dipilih protein jenis enzim, yaitu SOD, superoksida dismutase $(\mathrm{Cu} / \mathrm{Zn})$ dengan kode UniProt A0A0B6VWS2. Sekuen protein enzim SOD dengan kode A0A0B6VWS2 dalam format FASTA disajikan pada Gambar 1.

Sekuen protein SOD menunjukkan residu asam amino berjumlah 154. Data sekuen ini di-release pada tanggal 1 April 2015 oleh Kumaresan et al. [10]. Data sekuen ini digunakan untuk pembuatan model struktur 3D protein menggunakan server SWISS-MODEL. Penyalinan sekuen protein dari server UniProt ke server SWISS-MODEL dilakukan dengan menggunakan format FASTA seperti pada Gambar 1.

\section{>tr|A0A0B6VWS2 SOD[Cu-Zn] Channa striata MALKAVCVLKGAGETSGTVYFEQENPTAPVKVTGEIQGLTPGDHGFHVHAFGDNTNGC ISAGPHYNPHNKNHAGPNDEERHVGDLGNVIAGADNIAKINITDKI ITLSGPYSI IGR TMVIHEKADDLGKGGNEESLKTGNAGGRLACGVIGIAQ}

Gambar 1. Sekuen target protein SOD dalam format FASTA

\section{B. Identifikasi Template}

Data sekuen target protein dalam format FASTA seperti pada Gambar 1 di submit pada server SWISS-MODEL, https://swissmodel.expasy.org/. Template yang dihasilkan ada 50 buah. Pemilihan template didasarkan pada beberapa parameter antara lain: Coverage, nilai GMQE, nilai $Q S Q E$, Identity, Methods, Oligo Score dan Ligands. Parameter template yang dipilih adalah nilai GMQE tertinggi mendekati 1, nilai QSQE tertinggi mendekati 1, dan nilai identity diatas $70 \%$. Dari pertimbangan parameter tersebut maka dipilih template dengan kode 3gtv.1 [11]. Template dengan kode 3gtv.1 mempunyai nilai Identity 70.59\%, nilai parameter $G M Q E=0.89$, nilai $Q S Q E=0.99$, metode menggunakan X-ray 2,2 $\AA$ dan oligo state-nya adalah homo-dimer dengan ligan $\mathrm{Zn}$. 


\section{Pemodelan Sekuen Target}

Pemilihan template dengan kode 3gtv.1 menghasilkan 2 model, yaitu model-1 dan model-2. Model-1 mempunyai kode template 1q0e.1 adalah struktur kristal enzim superokside dismutase $(\mathrm{Cu}-\mathrm{Zn})$ dari Bos Taurus (bovine). Struktur ini di release pada tanggal 23 september 2003 oleh Hough et al. [12]. Model-2 dengan kode template 3gtv.1 adalah enzim Superokida dismutase $(\mathrm{Cu}-\mathrm{Zn})$ yang didapat dari Homo sapien dan Mus musculus. Struktur ini di release pada 8 September 2010 oleh Seetharaman et al. [10]. Beberapa parameter model-1 dan model-2 disajikan pada Tabel 1.

Tabel 1. Parameter Model-1 dan Model-2

\begin{tabular}{|l|c|c|}
\hline Parameter & Model-1 & Model-2 \\
\hline Template & 1q0e.1 & 3gtv.1 \\
\hline
\end{tabular}

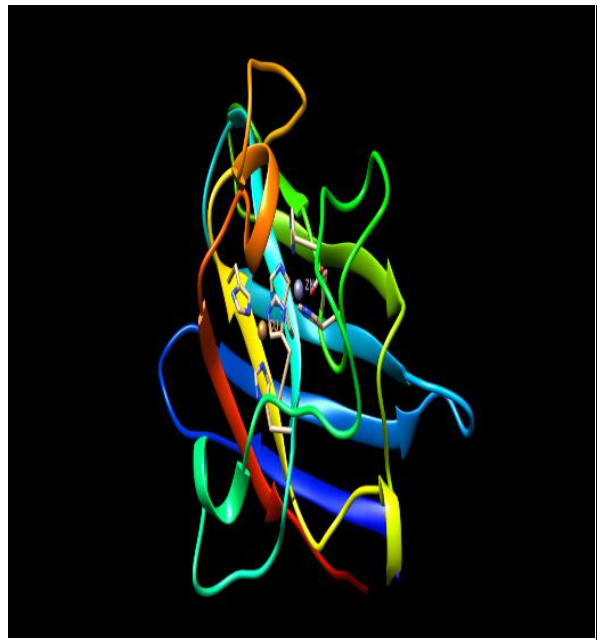

(a)

\begin{tabular}{|l|c|c|}
\hline Oligo state & Monomer & Homo-dimer \\
\hline Ligan & $\mathrm{Cu}, \mathrm{Zn}$ & $2 \mathrm{Zn}$ \\
\hline GMQE & 0.92 & 0.93 \\
\hline QMEAN & 1.13 & 0.94 \\
\hline QSQE & 0.00 & 0.99 \\
\hline Sequen identity & $70.86 \%$ & $70.59 \%$ \\
\hline Sequen similarity & 0.52 & 0.52 \\
\hline Coverage & 0.98 & 0.99 \\
\hline Methods & X-ray, 1.15 & X-ray, $2.20 \AA$ \\
\hline
\end{tabular}

Visualisai struktur Model-1 dan Model 2 menunjukkan adanya perbedaan pada ligan. Model-1 memiliki ligan logam $\mathrm{Cu}$ dan $\mathrm{Zn}$, sedang model-2 hanya memiliki ligan logam Zn. Struktur Model-1 dan Model-2 disajikan pada Gambar 2.

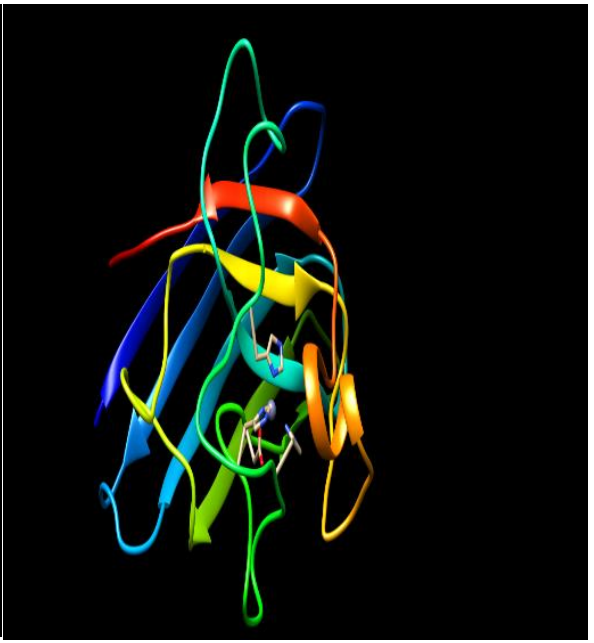

(b)

Gambar 2. (a) Model-1 dan (b) Model-2

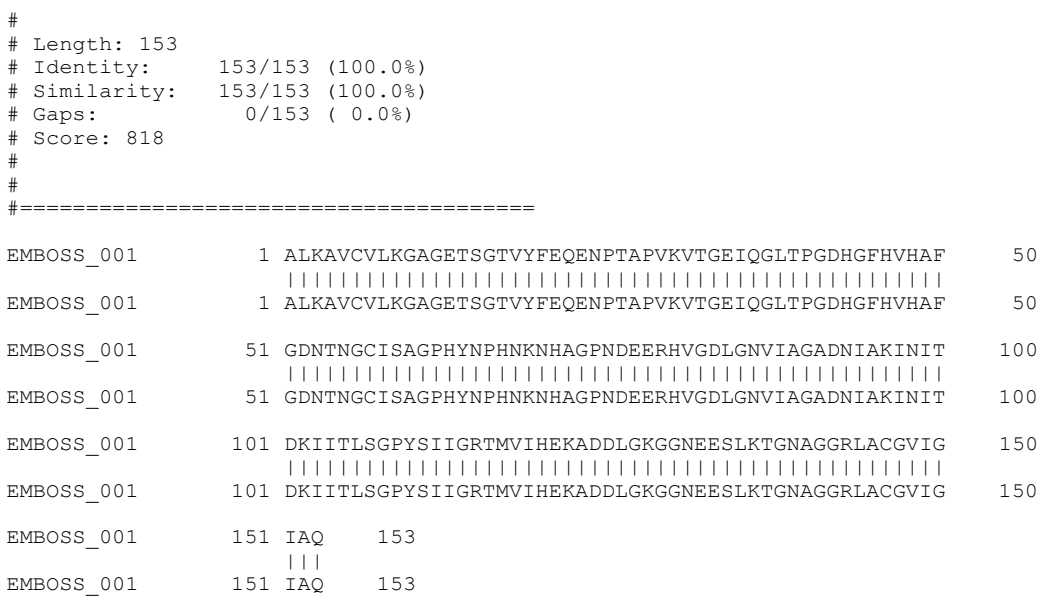

Gambar 3. Hasil Pensejajaran sekuen Protein Model-1 dan Model-2

Hasil pensejajaran sekuen protein model 1 dan model-2 menggunakan Pairwise Sequence Alignment pada server https://www.ebi.ac.uk/Tools/psa/ disajikan pada Gambar 3. Hasil pensejajaran sekuen protein model-1 dan model-2 menunjukkan nilai identity $100 \%$ dan nilai similarity $100 \%$, artinya secara struktur sekunder kedua model tersebut identik. Residu asam amino dari sekuen Model-1 dan Model-2 berjumlah 153. Ada 1 residu yang dibuang oleh server SWISS-MODEL, yaitu residu no 1, $\mathrm{M}=$ metionin. Satu residu yang dibuang ini untuk memperbaiki kualitas model.

Struktur 3D model-1 dan model-2 hasil visualisasi menggunakan program Chimera 1.14 juga menunjukkan struktur yang sama, kecuali pada ligan yang berbeda. 
Model-1 mempunyai 2 ligan logam, yaitu $\mathrm{Cu}$ dan $\mathrm{Zn}$, sedangkan pada model-2 mempunyai 1 ligan $\mathrm{Zn}$. Hasil mapping model-1 dan model-2 pada Gambar 4.

\section{Evaluasi model}

Evaluasi struktur model adalah bagian penting dalam pembuatan model [13]. Persen identity sekuen target dan template adalah penilaian awal terhadap kualitas model. Semakin besar persen identity antara sekuen dan target, maka model yang dibuat semakin mendekati yang sebenarnya. Nilai identity model-1 dan model-2 adalah adalah 70,59\% dengan menggunakan kode PDB: 3gtv.1 pada Chain: A sebagai template. Akurasi model sangat bervariasi tergantung pada tingkat homologi pensejajaran target template, kualitas template, fleksibilitas struktur dan akurasinya program pemodelan [14]. Hasil analisis pemodelan sekuen target menunjukkan model-1 dan model-2 adalah identik. Evaluasi model dilakukan dengan memilih salah satu dari kedua model tersebut. Model yang dipilih adalah nodel-1 sebagai obyek untuk evaluasi model.

Hasil pensejajaran sekuen antara model-1 dan template PDB ID 1q0e.1 dapat dilihat pada Gambar 5. Hasil pensejajaran sekuen protein model 1 dan PDB ID 1q0e.1 menggunakan Pairwise Sequence Alignment pada server https://www.ebi.ac.uk/Tools/psa/ menunjukkan nilai identity sebesar $69.9 \%$ sedangkan nilai similarity sebesar $79.1 \%$. Angka-angka ini menunjukkan variasi residu asam amino yang tidak sama.

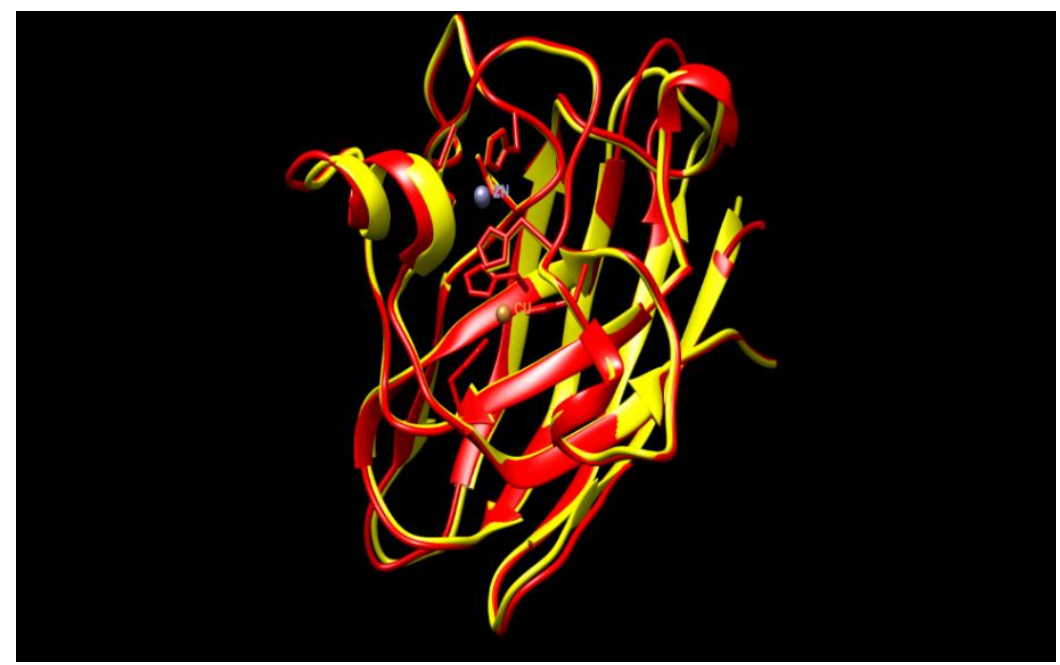

Gambar 4. Mapping Model-1 (merah) dan Model-2 (kuning)

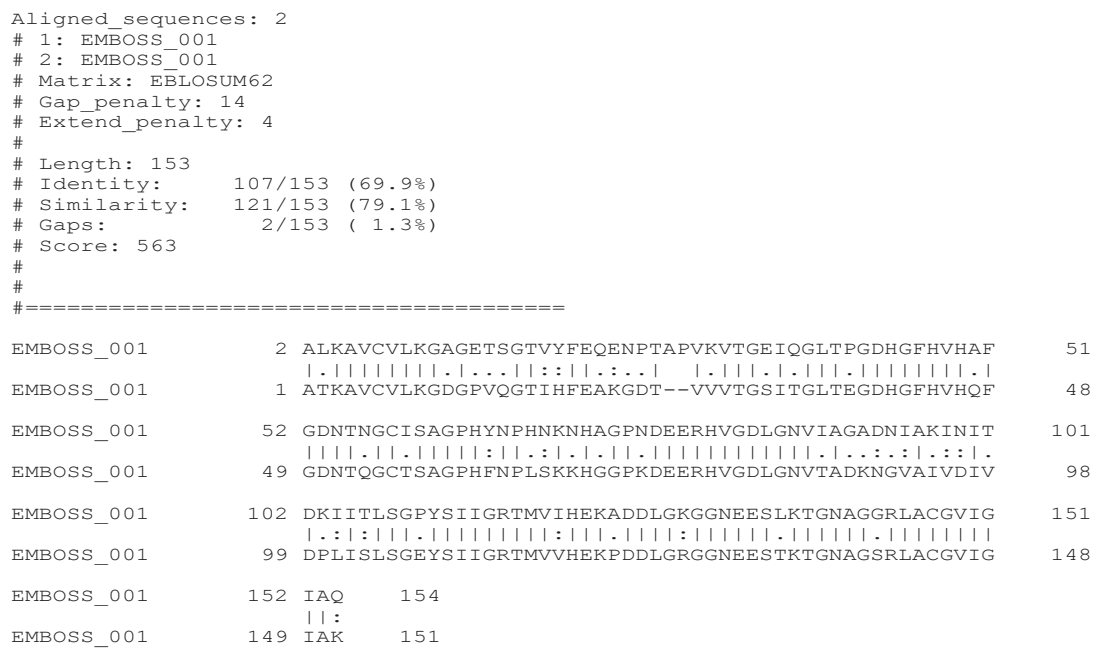

Gambar 5. Hasil pensejajaran sekuen protein model-1 dan PDB ID 1g0e.1 


\section{E. Penilaian Model}

Penilaian struktur protein model-1 pada server SWISSMODEL ditunjukkan pada parameter Ramachandran Plots dan MolProbity Results. Hasil Ramachadran Plots model-1 seperti pada Gambar 6.

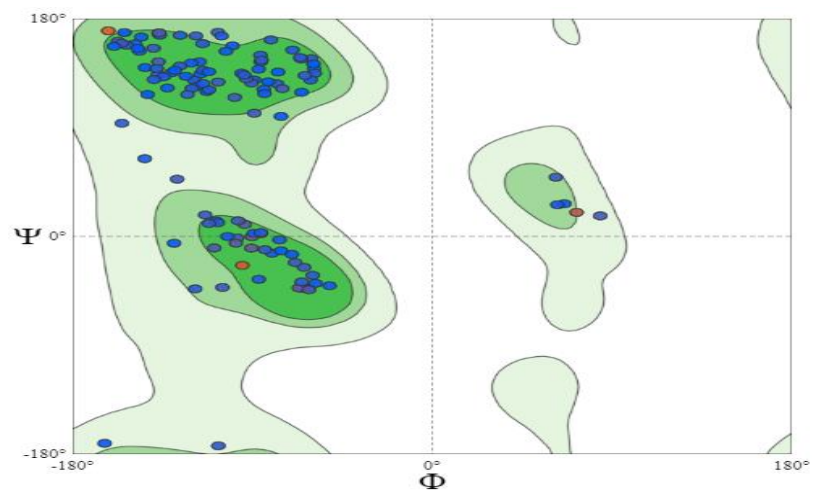

Gambar 6. Ramachandran Plots Model-1

Berdasarkan Ramachandran Plots, protein mempunyai kualitas struktur yang baik jika residu asam amino secara umum lebih banyak pada daerah favoured dibandingkan Outliers. Tabel 2 menunjukkan bahwa model-1 memiliki daerah favoured sebesar 97,36\% dan daerah outliers $0.66 \%$, artinya model tersebut sangat baik [15]. Sedangkan skor MolProbity dari model-1 sebesar 0.79, artinya model tersebut cukup baik. Skor MolProbity adalah kombinasi log-weighted dari clash score, persentase Ramachandran yang tidak disukai dan persentase rotamer rantai samping yang buruk. Skor ini menunjukkan satu nilai yang diharapkan untuk menggambarkan resolusi kristalografi. Jika struktur model mempunyai skor MolProbity lebih rendah di banding resolusi kristalografi sebenarnya, maka secara kualitas model tersebut dikatakan lebih baik daripada struktur rata-rata pada resolusi itu. Resolusi kristalografi template untuk model-1 adalah $1.15 \AA$ [16].
Tabel 2. Hasil analisis Model-1

\begin{tabular}{lll}
\hline MolProbity Score & 0.79 & \\
\hline Clash Score & 0.46 & \\
\hline Ramachandran Favoured & $97.35 \%$ & \\
\hline Ramachandran Outliers & $0.66 \%$ & A28 ALA \\
\hline Rotamer Outliers & $0.87 \%$ & A7 CYS \\
\hline C-Beta Deviations & 0 & \\
\hline Bad Bonds & $0 / 1131$ & \\
\hline Bad Angles & $11 / 1533$ & \\
& (A28 ALA-A29 PRO), A64 \\
& HIS, (A25 ASN-A26 PRO), \\
& A47 HIS, A72 HIS, (A121 \\
& HIS-A122 GLU), A68 HIS, \\
& A44 HIS, A138 THR, A121 \\
& HIS \\
\hline
\end{tabular}

Parameter lain yang dapat digunakan untuk menilai kualitas model adalah QMEAN. Website https://swissmodel.expasy.org/qmean/ digunakan untuk mengetahui parameter $Q M E A N$. QMEAN adalah fungsi penilaian gabungan yang dapat menentukan perkiraan kualitas absolut global (yaitu untuk seluruh struktur) dan lokal (yaitu per residu asam amino) berdasarkan satu model tunggal. Skore $Q M E A N$ aslinya berada dalam kisaran $0-1$, dimana nilai 1 berarti baik. Secara default, nilai tersebut diubah menjadi skor-Z untuk menghubungkannya dengan apa yang kita harapkan dari struktur sinar-X resolusi tinggi. Gambar 7 menggambarkan posisi model (tanda bintang merah) pada sebaran nilai Z. Tanda bintang merah masih berada pada daerah Z-score $<1$, artinya model masih cukup baik.

Perkiraan kualitas local model per residu asam amino dapat dilihat pada Gambar 8. Grafik tersebut menggambarkan hubungan kesamaan antara residu asam amino model (sebagai sumbu $\mathrm{x}$ ) dengan struktur asli (sumbu y). Secara umum residu asam amino yang menunjukkan skor di bawah 0.6 berkualitas rendah. Gambar 8 menunjukkan bahwa tidak ada asam amino yang mempunyai skore di bawah 0.6 , artinya kualitas residu asam amino model adalah baik.

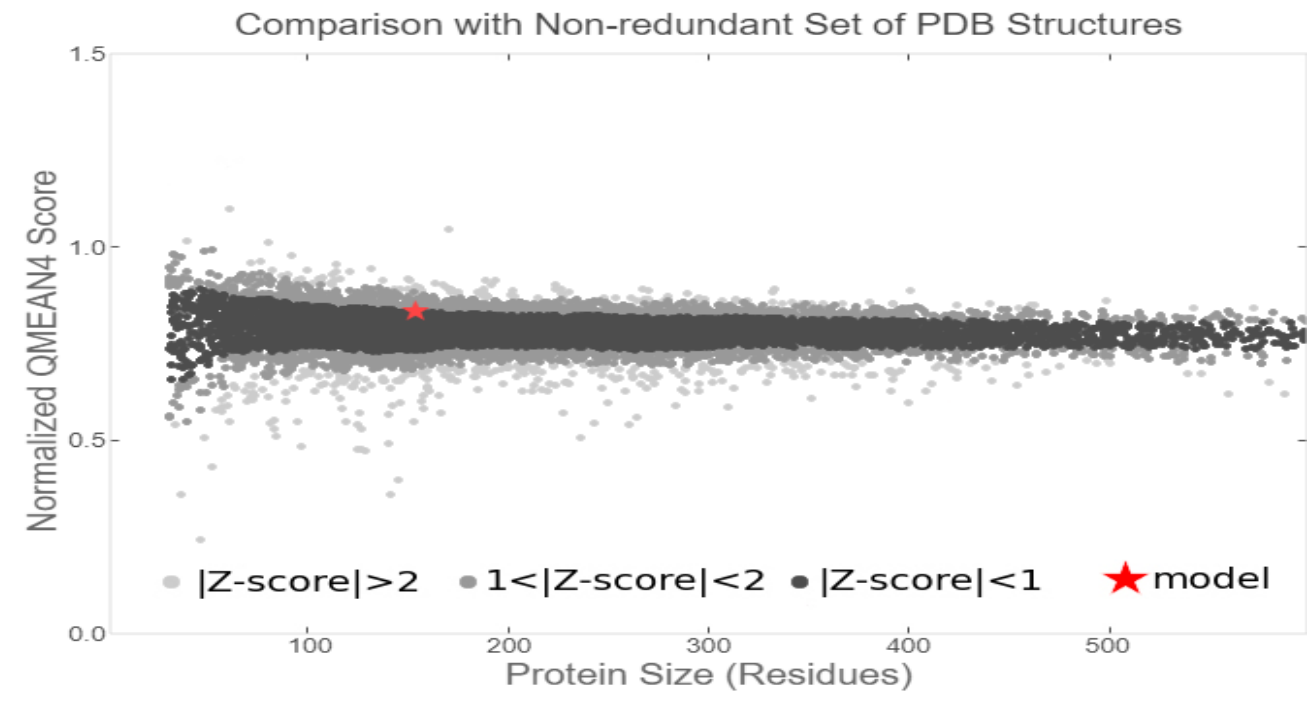

Gambar 7. Posisi Model (bintang merah) pada sebaran nilai Z 


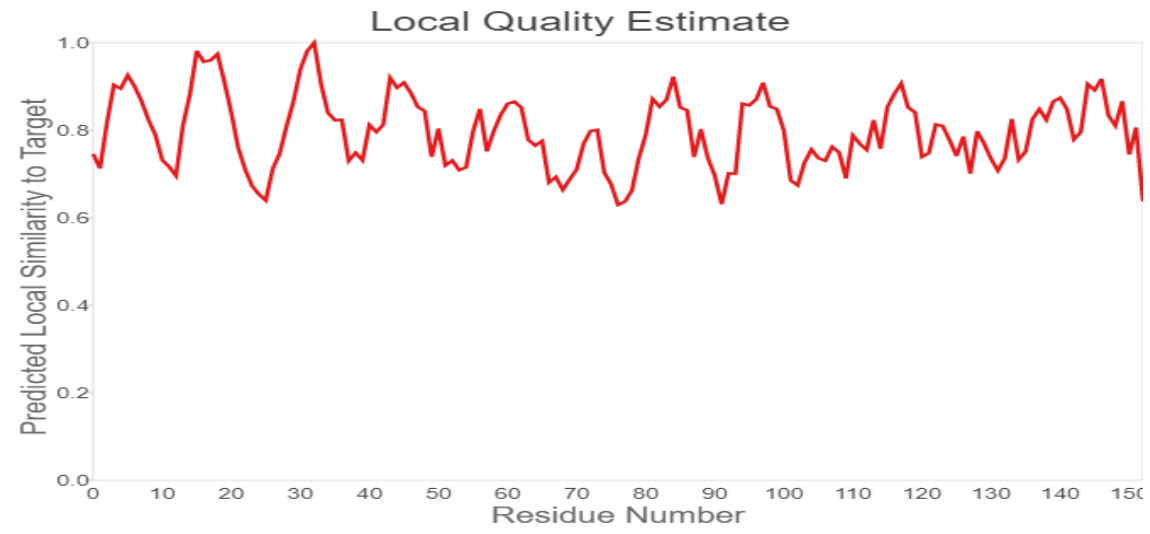

Gambar 8. Perkiraan kualitas lokal residu asam amino

\section{KESIMPULAN}

Pemodelan protein dengan sekuen dari UniProt kode AOAOB6VWS2 dengan metode homology modelling menggunakan program SWISS-MODEL menghasilkan model struktur 3D. Model-1 dengan kode template PDB 1q0e dan model-2 dengan kode template PDB 3gtv. Hasil pensejajaran sekuen dan visualisasi model menunjukkan bahwa model-1 dan model-2 adalah identik. Evaluasi dan penilaian model-1 pada Ramachandran Plots memiliki daerah favoured sebesar 97,36\%, skor MolProbity sebesar 0.79 dan harga QMEAN 1.13. Model-1 adalah model struktur 3D protein yang bernilai baik.

\section{REFERENSI}

[1] Wijaya, H. dan F. Hasanah, 2016. Prediksi Strukur Tiga Dimensi Protein Alergen Pangan Dengan Metode Homologi Menggunakan Program SWISS_MODEL, BioPropal Industri, Vol. 7 No.2, Desember 2016: 83-94, https://media.neliti.com/media/publications/53193-IDnone.pdf

[2] Zaki MJ, Bystroff C., 2008. "Protein structure prediction, Preface", Methods Mol Biol. 2008;413:v-vii. doi:10.1007/978-1-59745-574-9

[3] Saudale, Fredy. (2020). Pemodelan Homologi Komparatif Struktur 3d Protein dalam Desain dan Pengembangan Obat. Al-Kimia. 8. 10.24252/al-kimia.v8i1.9463.

[4] Kopp, J., Bordoli, L., Battey, J. N. D., Kiefer, F. \& Schwede, T. (2007). Assessment of CASP7 predictions for templatebased modeling targets. Proteins, 69 Suppl., 8, 38-46. doi:10.1002/prot.21753.

[5] Hillisch A, Pineda LF, Hilgenfeld R. Utility of homology models in the drug discovery process. Drug Discov Today. 2004;9(15):659-669. doi:10.1016/S1359-6446(04)03196-4

[6] Waterhouse, A., Bertoni, M., Bienert, S., Studer, G., Tauriello, G., Gumienny, R., Heer, F. T., de Beer, T., Rempfer, C., Bordoli, L., Lepore, R., \& Schwede, T. (2018). SWISS-MODEL: homology modelling of protein structures and complexes. Nucleic acids research, 46(W1), W296W303. https://doi.org/10.1093/nar/gky427

[7] Pearson W. R. (2013). An introduction to sequence similarity ("homology") searching. Current protocols in $\begin{array}{lccc}\text { bioinformatics, } & \text { Chapter } & 3, & \text { Unit3.1. } \\ \text { https://doi.org/10.1002/0471250953.bi0301s42 } & \end{array}$

[8] Prastari, C., S. Yasni, M. Nurilmala, 2017. Karakteristik Protein Ikan Gabus Yang Berpotensi sebagai AntiHiperglikemik, Jurnal Pengolahan Hasil Perikanan Indonesia (JPHPI), Volume 20 Nomor 2: 413-423, DOI: http://dx.doi.org/10.17844/jphpi.v20i2.18109

[9] Bordoli, Lorenza \& Kiefer, Florian \& Arnold, Konstantin \& Benkert, Pascal \& Battey, James \& Schwede, Torsten. (2009). Protein structure homology modelling using SWISS-MODEL workspace. Nature protocols. 4. 1-13. 10.1038/nprot.2008.197.

[10] Kumaresan V, Gnanam AJ, Pasupuleti M, et al. Comparative analysis of $\mathrm{CsCu} / \mathrm{ZnSOD}$ defense role by molecular characterization: gene expression-enzyme activity-protein level. Gene. 2015;564(1):53-62. doi:10.1016/j.gene.2015.03.042

[11] Seetharaman, S.V., Taylor, A.B., Holloway, S., Hart, P.J. (2010) Structures of mouse SOD1 and human/mouse SOD1 chimeras. Arch Biochem Biophys 503: 183-190. PubMed: 20727846, DOI: 10.1016/j.abb.2010.08.014

[12] Hough, M.A., Hasnain, S.S. (2003). Structure of fully reduced bovine copper zinc superoxide dismutase at $1.15 \mathrm{~A}$. Structure 11: 937-946 PubMed: 12906825. DOI: 10.1016/s0969-2126(03)00155-2

[13] Baker, D. \& Sali, A. (2001). Protein structure prediction and structural genomics. Science (New York, N.Y.), 294(5540), 93-6. doi:10.1126/science.1065659.

[14] Bordoli, L., Kiefer, F., Arnold, K., Benkert, P., Battey, J. \& Schwede, T. (2009). Protein structure homology modeling using SWISS-MODEL workspace. Nature Protocols, 4(1), 1-13. doi:10.1038/ nprot.2008.197.

[15] Sharma, Sunny \& Sarkar-Banerjee, Suparna \& Paul, Simanta \& Roy, Syamal \& Chattopadhyay, Krishnananda. (2014). srep03525-s1.

[16] Chen, V. B., Arendall, W. B., 3rd, Headd, J. J., Keedy, D. A., Immormino, R. M., Kapral, G. J., Murray, L. W., Richardson, J. S., \& Richardson, D. C. (2010). MolProbity: all-atom structure validation for macromolecular crystallography. Acta crystallographica. Section D, Biological crystallography, $66(\mathrm{Pt} 1), \quad 12-21$. https://doi.org/10.1107/S0907444909042073 